\title{
A Systematic Review of the Incidence and Prevalence of Long-Term Neurological Conditions in the UK
}

\author{
Thomas Hoppitt ${ }^{\mathrm{a}}$ Hardev Pall $^{\mathrm{b}}$ Mel Calvert ${ }^{\mathrm{a}}$ Paramjit Gill ${ }^{\mathrm{a}}$ Guiqing Yao ${ }^{\mathrm{a}}$ \\ Jill Ramsay ${ }^{a}$ Gill James ${ }^{a}$ Jacky Conduit ${ }^{a}$ Cath Sackley ${ }^{a}$ \\ ${ }^{a}$ School of Health and Population Sciences, and ${ }^{\mathrm{b}}$ School of Clinical and Experimental Medicine, \\ University of Birmingham, Birmingham, UK
}

\section{Key Words}

Motor neurone disease $\cdot$ Huntington's disease •

Multiple system atrophy · Progressive supranuclear palsy •

Charcot-Marie-Tooth disease $\cdot$ Postpolio syndrome .

Dominantly inherited ataxias

\begin{abstract}
Background: Updated, robust estimates of the incidence and prevalence of rare long-term neurological conditions in the UK are not available. Global estimates may be misrepresentative as disease aetiology may vary by location. Objectives: To systematically review the incidence and prevalence of long-term neurological conditions in the UK since 1988. Search Strategy: Medline (January 1988 to January 2009), Embase (January 1988 to January 2009), CINAHL (January 1988 to January 2009) and Cochrane CENTRAL databases. Selection Criteria: UK population-based incidence/prevalence studies of long-term neurological conditions since 1988. Exclusion criteria included inappropriate diagnoses and incomprehensive case ascertainment. Data Collection and Analysis: Articles were included based on the selection criteria. Data were extracted from articles with ranges of in-
\end{abstract}

cidence and prevalence reported. Main Results: Eight studies met the criteria ( 3 on motor neurone disease; 4 on Huntington's disease; 1 on progressive supranuclear palsy). The incidence of motor neurone disease ranged from 1.06 to $2.4 / 100,000$ person-years. The prevalence ranged from 4.02 to $4.91 / 100,000$. The prevalence of Huntington's disease ranged from 4.0 to $9.94 / 100,000$. The prevalence of progressive supranuclear palsy ranged from 3.1 to $6.5 / 100,000$. Conclusions: The review updates the incidence/prevalence of long-term neurological conditions. Future epidemiological studies must incorporate comprehensive case ascertainment methods and strict diagnostic criteria.

Copyright $\odot 2010$ S. Karger AG, Basel

\section{Introduction}

Progressive neurological diseases vary in presentation, both in timescale and severity. This review forms part of a Policy Research Programme commissioned by the National Institute for Health Research to assess disease burden on service user, family and health and social care services. The investigated conditions were requested by

\section{KARGER}

() 2010 S. Karger AG, Basel

Fax +41613061234

E-Mail karger@karger.ch

www.karger.com
Dr. Thomas Hoppitt

Primary Care Clinical Sciences

University of Birmingham

Edgbaston, Birmingham B15 2TT (UK)

Tel. +44 121414 8544, Fax +44 121414 6571, E-Mail t.j.hoppitt@bham.ac.uk 
the commission to encompass a range of aetiologies, symptoms, diagnoses and prognoses.

\section{Rationale and Aim of Review}

The aim was to systematically identify and update the incidence and prevalence of the following long-term neurological conditions:

- Motor neurone disease

- Huntington's disease

- Progressive supranuclear palsy

- Multiple system atrophy

- Postpolio syndrome

- Charcot-Marie-Tooth disease

- Dominantly inherited ataxias

Knowledge of these data is valuable in informing future research and health service policies.

\section{Methods}

The review protocol is accessible at http://www.ltnc.org.uk/ research_files/RESULT_study.html. Population-based studies of incidence and prevalence were sought.

\section{Scoping Search}

A scoping search identified existing reviews of incidence and prevalence. Existing reviews would be updated, not repeated. Medline (Ovid; 1950 to week 2 of 2009], Embase (Ovid; 1980 to week 46 of 2008], CINAHL (Ovid; 1982 to week 1 of 2009], the Science Citation Index, Cochrane Library (CENTRAL) and Centre for Reviews and Dissemination databases were searched.

\section{Main Search Strategy}

The search strategy (Appendix 1) identified articles from Medline, Embase and CINAHL. The Cochrane Library (CENTRAL) and databases of ongoing research and unpublished literature were also searched. Reference lists of included articles were assessed to capture further articles omitted from the search strategy.

\section{Inclusion/Exclusion Criteria}

Articles were included based on the criteria outlined in table 1. Comprehensive case ascertainment was required in order to ensure maximum patient capture. Studies before 1988 were excluded as the review aimed to present up-to-date statistics. Strict diagnostic criteria were set to minimise bias from misdiagnoses. Inclusion was based on agreement between 2 of the independent reviewers (T.H., J.C., G.J., J.R.). In cases of non-consensus, a third independent review was obtained. In cases of incomprehensive study methodology, authors were approached to determine a study's potential inclusion.

\section{Data Extraction}

The following data were extracted into tables:

- Source: authors and journal published

- Study design: e.g. cross-sectional, cohort, etc.

- Population denominator
Table 1. Selection criteria

Study design

- Population-based observational studies with a defined population denominator

- Comprehensive case ascertainment including steps to maximise the number of cases captured (e.g. multiple patient registers at multiple centres searched)

- Study conducted after 1988 (pre-1988 research would not provide recent statistics)

Population

- Persons with the long-term conditions of interest diagnosed by the criteria specified below ${ }^{1}$

- Resident in the UK

Outcomes

- Prevalence/incidence of long-term conditions in the UK

${ }^{1}$ Diagnostic criteria available in Appendix 2.
- Timescale: incidence time frame and prevalence date

- Case ascertainment method

- Diagnostic method

- Outcome: incidence per 100,000 person-years; prevalence per 100,000 of population

- Methodological limitations

- Potential bias

Data Analyses

Incidences were reported as ranges. Pooling statistics was not possible due to methodological heterogeneity and shared population denominations between certain studies.

\section{Results}

\section{Existing Systematic Reviews}

No existing systematic reviews of incidence and prevalence were identified.

\section{Study Yield}

The initial search yielded 8,869 references; 311 were identified as potentially relevant. Of these, 9 met the inclusion criteria and were included in the review (fig. 1).

\section{Included Studies by Condition}

Motor Neurone Disease (Amyotrophic Lateral

Sclerosis)

Five studies assessed the incidence/prevalence of motor neurone disease (table 2). Total population coverage was $11,498,075$, although some overlap between studies emerged. The incidence of motor neurone disease in the UK ranged from 1.06 to $2.4 / 100,000$ person-years (in- 
Fig. 1. Flowchart of included/excluded articles.

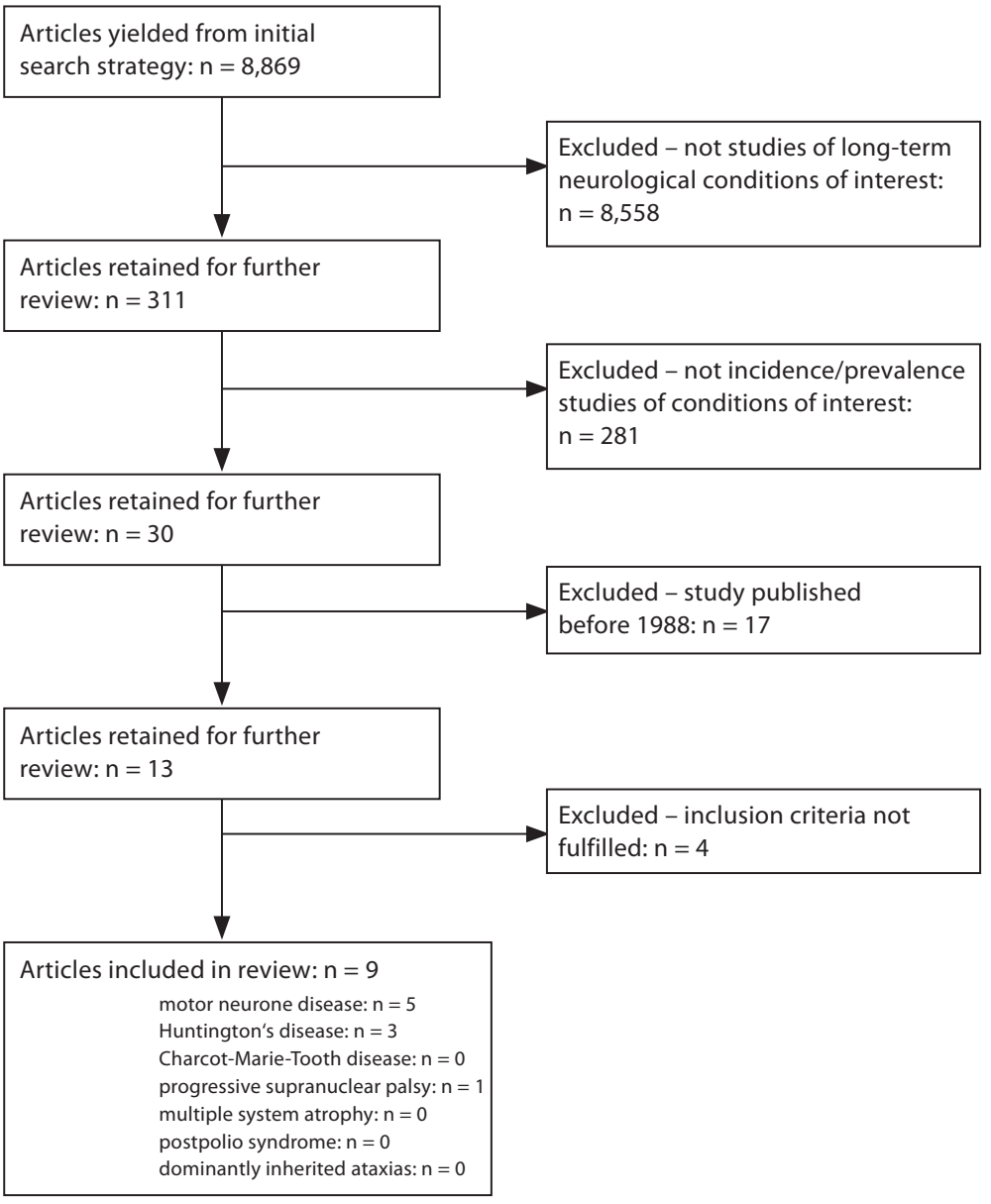

cluding all diagnostic categories of the World Federation of Neurology, WFN, and El Escorial criteria). The prevalence ranged from 4.02 to $4.91 / 100,000$ of the populations studied.

\section{Huntington's Disease}

Three studies assessed the prevalence of Huntington's disease (table 3). No reports of incidence were identified. Total population coverage was $5,483,871$. The prevalence ranged from 4.0 to $6.4 / 100,000$ of the populations studied.

\section{Progressive Supranuclear Palsy}

One study assessed the prevalence of progressive supranuclear palsy (table 4). The study included 3 substudies. A national study of the entire UK population, a re- gional study covering a catchment of 2,598,240 and a community study covering a catchment of 259,998 people. The prevalence ranged from $1.0 / 100,000$ in the national study to $6.5 / 100,000$ in the community study. However, only the community study had a comprehensive case ascertainment and we therefore report these statistics in our results.

\section{Results Summary}

Table 5 illustrates a summary of results identified in the study.

\section{Excluded Studies}

Four studies illustrated in table 6 were excluded from the review. 


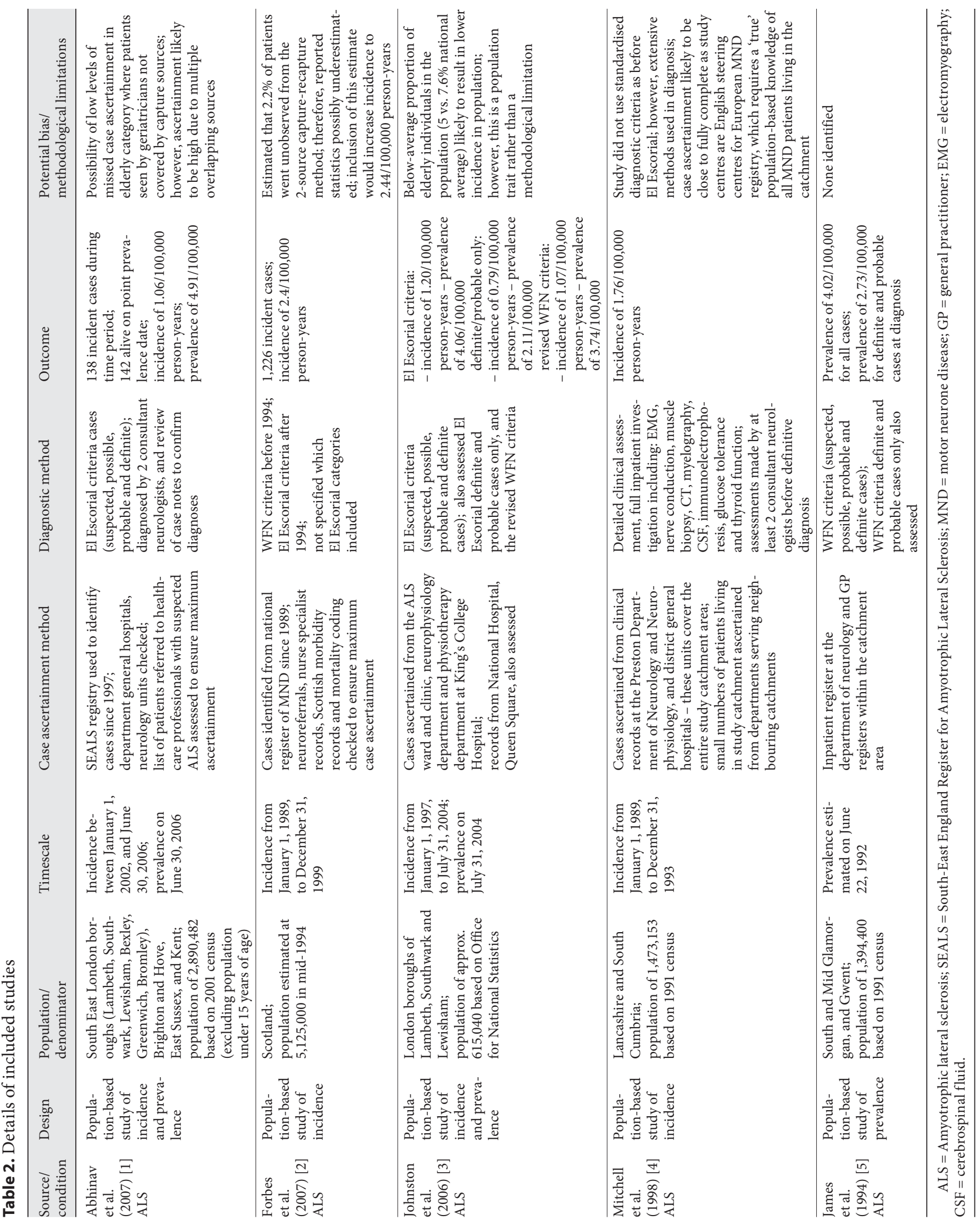


Table 3. Details of included studies

\begin{tabular}{|c|c|c|c|c|c|c|c|}
\hline $\begin{array}{l}\text { Source/ } \\
\text { condition }\end{array}$ & Design & $\begin{array}{l}\text { Population/ } \\
\text { denominator }\end{array}$ & Timescale & $\begin{array}{l}\text { Case ascertainment } \\
\text { method }\end{array}$ & $\begin{array}{l}\text { Diagnostic } \\
\text { method }\end{array}$ & Outcome & $\begin{array}{l}\text { Potential bias/ } \\
\text { methodological } \\
\text { limitations }\end{array}$ \\
\hline $\begin{array}{l}\text { Morrison } \\
\text { et al. } \\
\text { (1995) [6] } \\
\text { HD }\end{array}$ & $\begin{array}{l}\text { Population- } \\
\text { based study } \\
\text { of } \\
\text { prevalence }\end{array}$ & $\begin{array}{l}\text { Northern Ireland } \\
\text { population of } \\
1,569,971 \text { based } \\
\text { on } 1991 \text { national } \\
\text { census }\end{array}$ & $\begin{array}{l}\text { Prevalence } \\
\text { estimated on } \\
\text { April 21, } 1991\end{array}$ & $\begin{array}{l}\text { Northern Ireland } \\
\text { GP records; neurolo- } \\
\text { gist, psychiatrist and } \\
\text { geriatrician records; } \\
\text { Department of Medical } \\
\text { Genetics diagnostic } \\
\text { records }\end{array}$ & $\begin{array}{l}\text { DNA-confirmed } \\
\text { diagnoses for all } \\
\text { patients }\end{array}$ & $\begin{array}{l}\text { Prevalence of } \\
6.4 / 100,000\end{array}$ & $\begin{array}{l}\text { Small founder effect } \\
\text { due to large families; } \\
\text { however, families not } \\
\text { large enough to cause } \\
\text { bias in population } \\
\text { statistics }\end{array}$ \\
\hline $\begin{array}{l}\text { James } \\
\text { et al. } \\
\text { (1994) [7] } \\
\text { HD }\end{array}$ & $\begin{array}{l}\text { Population- } \\
\text { based study } \\
\text { of } \\
\text { prevalence }\end{array}$ & $\begin{array}{l}\text { South and Mid } \\
\text { Glamorgan, and } \\
\text { Gwent; } \\
\text { population of } \\
1,393,900 \text { based } \\
\text { on } 1991 \text { national } \\
\text { census }\end{array}$ & $\begin{array}{l}\text { Prevalence esti- } \\
\text { mated on } \\
\text { March } 1,1994\end{array}$ & $\begin{array}{l}\text { HD register for South } \\
\text { Wales }\end{array}$ & $\begin{array}{l}\text { Details of } \\
\text { formal diagnosis } \\
\text { in register; } \\
\text { notes of } \\
\text { symptom type } \\
\text { and onset } \\
\text { provided }\end{array}$ & $\begin{array}{l}\text { Prevalence of } \\
6.2 / 100,000\end{array}$ & $\begin{array}{l}\text { All known living cases } \\
\text { of HD studied; } \\
\text { potential for cases not } \\
\text { included in register, } \\
\text { and subsequent } \\
\text { underestimation of } \\
\text { prevalence }\end{array}$ \\
\hline $\begin{array}{l}\text { Watt and } \\
\text { Seller } \\
(1993)[8] \\
\text { HD }\end{array}$ & $\begin{array}{l}\text { Population- } \\
\text { based study } \\
\text { of } \\
\text { prevalence }\end{array}$ & $\begin{array}{l}\text { Oxford Region } \\
\text { Health Authority } \\
\text { under NHS; } \\
\text { population of } \\
2,520,000\end{array}$ & $\begin{array}{l}\text { Prevalence } \\
\text { estimated on } \\
\text { live patients on } \\
\text { January } 1,1988\end{array}$ & $\begin{array}{l}\text { Oxford region medical } \\
\text { genetics department } \\
\text { records; } \\
\text { it is thought by the time } \\
\text { of the study all persons } \\
\text { affected in } 1988 \text { would } \\
\text { have been referred and } \\
\text { ascertained }\end{array}$ & $\begin{array}{l}\text { Confirmed by } \\
\text { presymptomatic } \\
\text { linkage test }\end{array}$ & $\begin{array}{l}\text { Prevalence of } \\
4.0 / 100,000\end{array}$ & None identified \\
\hline
\end{tabular}

HD = Huntington's disease; NHS = National Health Service; GP = general practitioner.

Table 4. Details of included studies

\begin{tabular}{|c|c|c|c|c|c|c|c|}
\hline $\begin{array}{l}\text { Source/ } \\
\text { condition }\end{array}$ & Design & $\begin{array}{l}\text { Population/ } \\
\text { denominator }\end{array}$ & Timescale & $\begin{array}{l}\text { Case ascertainment } \\
\text { method }\end{array}$ & $\begin{array}{l}\text { Diagnostic } \\
\text { method }\end{array}$ & Outcome & $\begin{array}{l}\text { Potential bias/ } \\
\text { methodological } \\
\text { limitations }\end{array}$ \\
\hline $\begin{array}{l}\text { Nath } \\
\text { et al. } \\
\text { (2001) [9] } \\
\text { PSP }\end{array}$ & $\begin{array}{l}\text { Popula- } \\
\text { tion- } \\
\text { based } \\
\text { study of } \\
\text { preva- } \\
\text { lence }\end{array}$ & $\begin{array}{l}3 \text { substudies; } \\
\text { - National study: } \\
\text { population of } 59,236,500 \\
\text { - North East study: } \\
\text { population of } 2,589,240 \\
\text { - Community study } \\
\text { (35 GP catchments in } \\
\text { Newcastle-upon-Tyne): } \\
\text { population of } 259,998 ; \\
\text { populations all based on } \\
1998 \text { census figures for } \\
\text { the UK }\end{array}$ & $\begin{array}{l}\text { Preva- } \\
\text { lence on } \\
\text { January 1, } \\
1999\end{array}$ & $\begin{array}{l}\text { - National study: } \\
\text { case ascertainment not } \\
\text { complete } \\
\text { - Regional study: direct } \\
\text { referral of cases from all } \\
\text { neurologists in the region, } \\
\text { correspondence reviews, } \\
\text { database screening, } \\
\text { inpatient hospital sources } \\
\text { - Community study: } \\
\text { screening of GP records for } \\
\text { potential patients followed } \\
\text { by review of records and } \\
\text { structured interview and } \\
\text { clinical examination }\end{array}$ & $\begin{array}{l}\text { Possible or } \\
\text { probable } \\
\text { cases based } \\
\text { on } \\
\text { NINDS- } \\
\text { SPSP crite- } \\
\text { ria }\end{array}$ & $\begin{array}{l}\text { - National study: } \\
\text { prevalence of } \\
1.0 / 100,000 \\
\text { - Regional study: } \\
\text { prevalence of } \\
3.1 / 100,000 \\
\text { - Community } \\
\text { study: } \\
\text { prevalence of } \\
6.5 / 100,000\end{array}$ & $\begin{array}{l}\text { Smaller population } \\
\text { denominator at each } \\
\text { level of study led to } \\
\text { more extensive capture } \\
\text { methods, hence the } \\
\text { greater prevalence in } \\
\text { smaller denomination } \\
\text { studies; } \\
\text { national study did not } \\
\text { use active case ascertain- } \\
\text { ment methods and } \\
\text { thought up to } 81 \% \text { of } \\
\text { cases unidentified }\end{array}$ \\
\hline
\end{tabular}

PSP = Progressive supranuclear palsy; GP = general practitioner; NINDS-SPSP = National Institute of Neurological Disorders and Society for Progressive Supranuclear Palsy. 


\section{Unreported Conditions}

No articles relating to postpolio syndrome, CharcotMarie-Tooth disease, multiple system atrophy and dominantly inherited ataxias in the UK were identified that met the inclusion criteria. However, some studies were identified that did not meet the required criteria. Whilst it would be inappropriate to include these studies in the results, table 7 provides incidence and prevalence statistics for excluded studies in conditions not represented in the results to provide at least some information on these conditions. However, one must view these results with caution due to the associated methodological limitations.

\section{Discussion}

The review aimed to systematically report the incidence and prevalence of long-term neurological conditions in the UK. Review findings and the variation between studies are discussed.

\section{Motor Neurone Disease}

Some variation in incidence is evident. An incidence of 1.06/100,000 person-years was found in South East England [1], compared to 2.4 in Scotland [2]. Differences in age structure between geographical locations may influence variations in incidence and prevalence rates. The literature suggests that onset generally occurs after 40 years age, with a peak incidence between 55 and 75 years $[14,15]$. Data from the 2001 census $[16,17]$ indicate that $32 \%$ of the population of Greater London are over 45 years of age compared to $40 \%$ of the Scottish population. Furthermore, approximately $10 \%$ of the Greater London population are in the 60- to 75 -year age bracket compared to $14 \%$ in Scotland. Such statistics are likely to make small differences in incidence and prevalence rates but would not account for any large differences. Other than these geographical considerations, there is no evidence of environmental factors to explain differences. Familial cases are reported as less than $10 \%$, making it unlikely that geographical clustering of families with motor neurone disease affected observed figures. Methodological differences within the study design may explain observed differences. Omissions of small numbers of unidentified cases could influence rates reported substantially. However, case ascertainment and diagnostic methods appear similar, and differences could be attributable to chance.

The prevalence was consistent across studies, ranging from 4.02 to $4.91 / 100,000$. These figures sit at the lower
Table 5. Ranges of prevalence/incidence of the long-term conditions

\begin{tabular}{|c|c|c|}
\hline & $\begin{array}{l}\text { Incidence range, } \\
\text { cases per } \\
100,000 \\
\text { person-years }\end{array}$ & $\begin{array}{l}\text { Prevalence } \\
\text { range, cases per } \\
100,000 \\
\text { of population }\end{array}$ \\
\hline Motor neurone disease & $1.06-2.4$ & $4.02-4.91$ \\
\hline Huntington's disease & not reported & $4.0-6.4$ \\
\hline Progressive supranuclear palsy & not reported & 6.5 \\
\hline Multiple system atrophy & not reported & not reported \\
\hline Dominantly inherited ataxias & not reported & not reported \\
\hline Charcot-Marie-Tooth disease & not reported & not reported \\
\hline Postpolio syndrome & not reported & not reported \\
\hline
\end{tabular}

end of the reported global prevalence $(4-10 / 100,000)[18-$ $22]$. However, it is worth noting that the actual prevalence may be higher as those without a diagnosis are not included in these estimates.

\section{Huntington's Disease}

The prevalence ranged from 4.0 to $6.4 / 100,000$. This is contrary to reported global rates $(0.4-0.5 / 100,000)$, but comparable to the prevalence reported in other Western countries $(8-10 / 100,000)$ [23].

Differences in prevalence between studies could be attributable to geographical variation due to the hereditary nature of the disease. A previous study reported a prevalence of 9.94/100,000 in the Grampian region of Scotland in 1987 [13], compared to 4.0/100,000 in Oxfordshire in 1993 [8]. Authors report the Grampian region to have low migration levels due to thriving local communities, compared to relatively high migration in the Oxfordshire region. A closed gene pool population compared to a population with high migration rates may explain such discrepancies.

The possibility of methodological differences between studies remains and could be a factor in reported discrepancies. Case ascertainment appears consistent between the studies. However, some studies used a genetic test as a diagnostic confirmation [6], whereas others appeared to assess records and registers for diagnostic confirmation [7]. Consequently, in studies using genetic testing, positive diagnoses were made for presymptomatic patients, which was not possible in studies where only symptomatic patients were included. As mentioned previously, in rare conditions incomplete case ascertainment or disease misclassification can skew the reported incidence/prevalence significantly in both directions. 
Table 6. Excluded studies

\begin{tabular}{lll}
\hline & Disease & Reason for exclusion \\
\hline $\begin{array}{l}\text { Craig et al. } \\
(2005)[10]\end{array}$ & $\begin{array}{l}\text { Dominantly inherited } \\
\text { ataxias }\end{array}$ & $\begin{array}{l}\text { Incomprehensive case ascertainment: investigation of a cohort of families with } \\
\text { undiagnosed ataxias and suspected Huntington's disease; there may be additional } \\
\text { cases outside the cohort studied, hence incomplete case ascertainment }\end{array}$ \\
\hline $\begin{array}{ll}\text { Craig et al. } \\
(2004) \text { [1] }\end{array}$ & $\begin{array}{l}\text { Dominantly inherited } \\
\text { ataxias }\end{array}$ & $\begin{array}{l}\text { Incomprehensive case ascertainment: investigation of already clinically affected } \\
\text { families; no broader searches, therefore possibility of further cases in families not } \\
\text { studied, hence incomplete case ascertainment possible }\end{array}$ \\
\hline $\begin{array}{l}\text { Schrag et al. } \\
(1999) \text { [12] }\end{array}$ & $\begin{array}{l}\text { Multiple system } \\
\text { atrophy/progressive } \\
\text { supranuclear palsy }\end{array}$ & $\begin{array}{l}\text { Incomprehensive case ascertainment: 33/202 patients (16\%) identified as potential } \\
\text { progressive supranuclear palsy/multiple system atrophy patients declined to be } \\
\text { assessed further, therefore complete case ascertainment was not possible; estimates } \\
\text { of incidence/prevalence are likely to be too low }\end{array}$ \\
\hline $\begin{array}{l}\text { Simpson and } \\
\text { Johnston (1989) [13] }\end{array}$ & $\begin{array}{l}\text { Huntington's disease } \\
\text { Although study published after 1988, data refer to pre-1988 incidence and prevalence }\end{array}$ \\
\hline
\end{tabular}

Table 7. Details of excluded studies of conditions not represented in the review

\begin{tabular}{|c|c|c|c|c|c|c|}
\hline $\begin{array}{l}\text { Source/ } \\
\text { condition }\end{array}$ & Design & $\begin{array}{l}\text { Population/ } \\
\text { denominator }\end{array}$ & Timescale & $\begin{array}{l}\text { Case ascertainment } \\
\text { method }\end{array}$ & Diagnostic method & Outcome \\
\hline $\begin{array}{l}\text { Schrag } \\
\text { et al. } \\
\text { (1999) [12] } \\
\text { MSA/PSP }\end{array}$ & $\begin{array}{l}\text { Population- } \\
\text { based study } \\
\text { of incidence } \\
\text { and } \\
\text { prevalence }\end{array}$ & $\begin{array}{l}15 \text { general } \\
\text { practices from } \\
\text { a linkage } \\
\text { scheme in the } \\
\text { London region; } \\
\text { population of } \\
121,608\end{array}$ & $\begin{array}{l}\text { Prevalence } \\
\text { on July 1, } \\
1997\end{array}$ & $\begin{array}{l}\text { Computerised records } \\
\text { screened, with deliberate } \\
\text { overascertainment to } \\
\text { include all possible cases; } \\
\text { neurologist reviewed } \\
\text { eligible records and } \\
\text { excluded where } \\
\text { appropriate; } 241 \text { eligible } \\
\text { patients, } 202 \text { agreed to be } \\
\text { assessed for diagnosis }\end{array}$ & $\begin{array}{l}\text { Computerised records } \\
\text { reviewed; } \\
\text { neurological interview } \\
\text { and assessment } \\
\text { including question- } \\
\text { naires and video to } \\
\text { capture neurological } \\
\text { symptoms; } \\
\text { longitudinal assess- } \\
\text { ments to identify } \\
\text { developing symptoms } \\
\text { of conditions }\end{array}$ & $\begin{array}{l}\text { - PSP: } 5 \text { diagnosed with probable PSP } \\
\text { and } 1 \text { possible PSP; crude prevalence } \\
\text { of } 4.9 / 100,000 \text { ( } 95 \% \text { CI: } 1.8-10.7) \text {; } \\
\text { probable only cases - prevalence of } \\
4.1 / 100,000 \\
\text { - MSA: } 2 \text { diagnosed with probable } \\
\text { MSA, } 1 \text { possible MSA; crude prevalence } \\
\text { of } 3.3 / 100,000 \text { ( } 95 \% \text { CI: } 0.9-8.4) \text {; } \\
\text { probable only cases - prevalence of } \\
1.6 / 100,000\end{array}$ \\
\hline $\begin{array}{l}\text { Craig } \\
\text { et al. } \\
(2004)[11] \\
\text { SCA6 }\end{array}$ & $\begin{array}{l}\text { Population- } \\
\text { based study } \\
\text { of } \\
\text { prevalence }\end{array}$ & $\begin{array}{l}\text { North-east } \\
\text { government } \\
\text { region; } \\
\text { population of } \\
2,516,500\end{array}$ & $\begin{array}{l}\text { Prevalence } \\
\text { on June } 30 \text {, } \\
2001\end{array}$ & $\begin{array}{l}\text { SCA6 families identified } \\
\text { and studied }\end{array}$ & $\begin{array}{l}\text { Molecular genetic and } \\
\text { haplotype analyses }\end{array}$ & $\begin{array}{l}32 \text { affected individuals from } 16 \\
\text { genealogically distinct families; DNA } \\
\text { only available for } 26 \text {; } \\
\text { minimum prevalence of } 1.59 / 100,000 \\
\text { (95\% CI: } 1.04-2.14 \text { ) in population aged } \\
\text { over } 16 \text { years, and of } 3.18 / 100,000 \text { ( } 95 \% \\
\text { CI: } 2.08-4.28 \text { ) in those }>45 \text { years old }\end{array}$ \\
\hline $\begin{array}{l}\text { Craig } \\
\text { et al. } \\
(2005)[10] \\
\text { SCA17 }\end{array}$ & $\begin{array}{l}\text { Population- } \\
\text { based study } \\
\text { of } \\
\text { prevalence }\end{array}$ & $\begin{array}{l}\text { North-east } \\
\text { government } \\
\text { region; } \\
\text { population of } \\
2,516,500\end{array}$ & $\begin{array}{l}\text { Prevalence } \\
\text { on June } 30 \text {, } \\
2001\end{array}$ & $\begin{array}{l}192 \text { families with } \\
\text { undiagnosed ataxia } \\
\text { and } 90 \text { families with } \\
\text { suspected Huntington's } \\
\text { disease studied }\end{array}$ & $\begin{array}{l}\text { Molecular genetic and } \\
\text { haplotype analyses }\end{array}$ & $\begin{array}{l}2 \text { patients identified with CAG } \\
\text { expansion greater than control; each } \\
\text { had an affected sister; } \\
\text { minimum prevalence of } 0.16 / 100,000 \\
\text { (95\% CI, upper value: } 0.31 \text { ) }\end{array}$ \\
\hline
\end{tabular}

MSA = Multiple system atrophy; PSP = progressive supranuclear palsy; SCA = spinocerebellar ataxia.

\section{Progressive Supranuclear Palsy}

Evidence suggests progressive supranuclear palsy is sporadic. Tau gene mutations have been identified as a predisposition. However, two thirds of the global population possess this polymorphism. Consequently, other factors may be more important in progressive supranuclear palsy.

The prevalence ranged from $1.0 / 100,000$ in the national study by Nath et al. [9] to 6.5/100,000 in the community study by the same authors. However, the authors ad- 
mit the case ascertainment was not 'active' and fully comprehensive due to the denominator size and report that $81 \%$ of the cases may be unascertained based on the community study prevalence. The regional study fits within the reported global prevalence range $(1.39-5.8 / 100,000)$ [24-26]. As the condition is sporadic, the greater prevalence observed in the community study is probably due to a more complete case ascertainment.

\section{General Points}

A fundamental point is that the incidence and prevalence reported should be regarded as minimum figures. Assuming studies had $100 \%$ case ascertainment of diagnosed patients, the statistics would still omit undiagnosed patients. Consequently, such studies will underpredict incidence and prevalence. One could argue that due to the lack of firm diagnostic criteria, diagnoses may switch between conditions, resulting in under- and overestimation of figures. However, misclassifications and changes in diagnoses would have insignificant bearing on statistics in comparison to the magnitude of effect of an exclusion of undiagnosed patients.

\section{Non-Reported Conditions}

No studies of the incidence/prevalence of CharcotMarie-Tooth disease or postpolio syndrome were identified. In Charcot-Marie-Tooth disease, this was surprising as it is reported as the most prevalent condition in global studies [27]. Furthermore, one may expect more extensive research with follow-up in a non-life-limiting condition. With regard to postpolio syndrome, despite a number of intervention trials [28-33], the lack of reported incidence/prevalence may reflect difficulties in confirming diagnoses due to the symptoms being similar to those associated with natural ageing. Accurate case ascertainment would be difficult and expose statistics to bias.

\section{Conclusion}

In conclusion, the review reported incidence/prevalence ranges for the long-term neurological conditions from all identified studies in the UK since 1988. The rates varied between studies, particularly for Huntington's disease, possibly attributable to geographical variation. The exclusion of articles due to methodological limitations suggests future epidemiological studies require comprehensive case ascertainment and strict and standardised diagnostic methods. Such safeguards will ensure more comprehensive reviews of incidence and prevalence, covering a wider denominator population of the UK.

\section{Appendix 1}

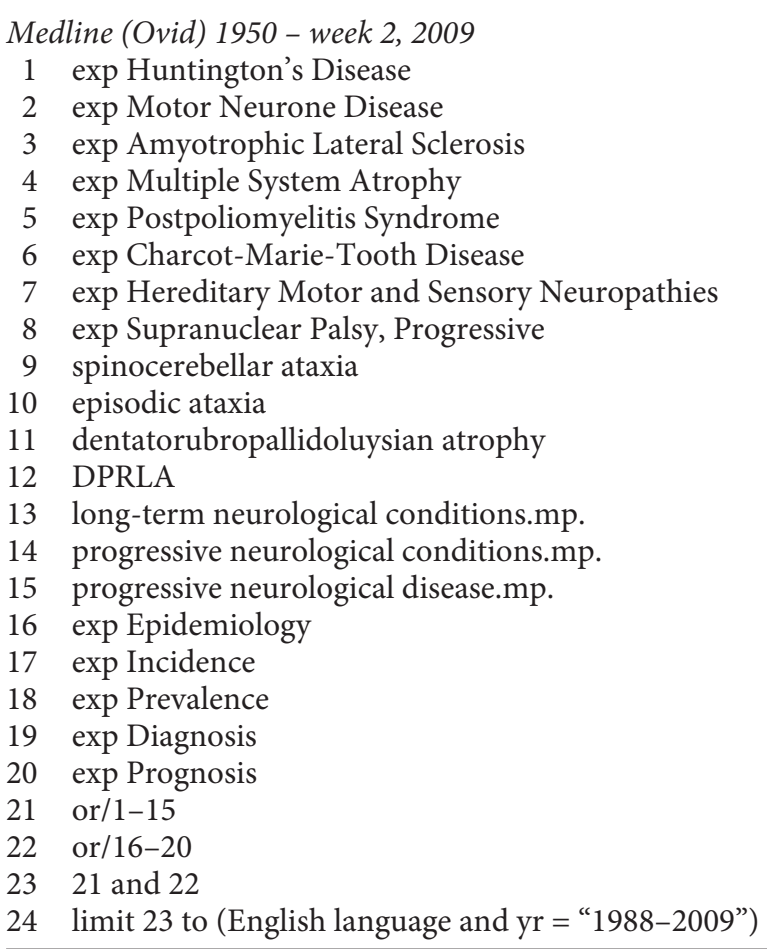

Embase (Ovid) 1980 - week 46, 2008

1 exp Huntington's Disease

2 exp Motor Neurone Disease

3 exp Amyotrophic Lateral Sclerosis

4 exp Multiple System Atrophy

5 exp Postpoliomyelitis Syndrome

6 exp Charcot-Marie-Tooth Disease

7 exp "Hereditary Motor and Sensory Neuropathies"

8 exp Supranuclear Palsy, Progressive

9 spinocerebellar ataxia

10 episodic ataxia

11 dentatorubropallidoluysian atrophy

12 DPRLA

13 long-term neurological conditions.mp.

14 progressive neurological conditions.mp.

15 progressive neurological disease.mp.

16 exp Epidemiology

17 exp Incidence

18 exp Prevalence

19 exp Diagnosis

20 exp Prognosis

21 or/1-15

22 or/16-20

2321 and 22

24 limit 23 to (English language and yr = "1988-2009”) 


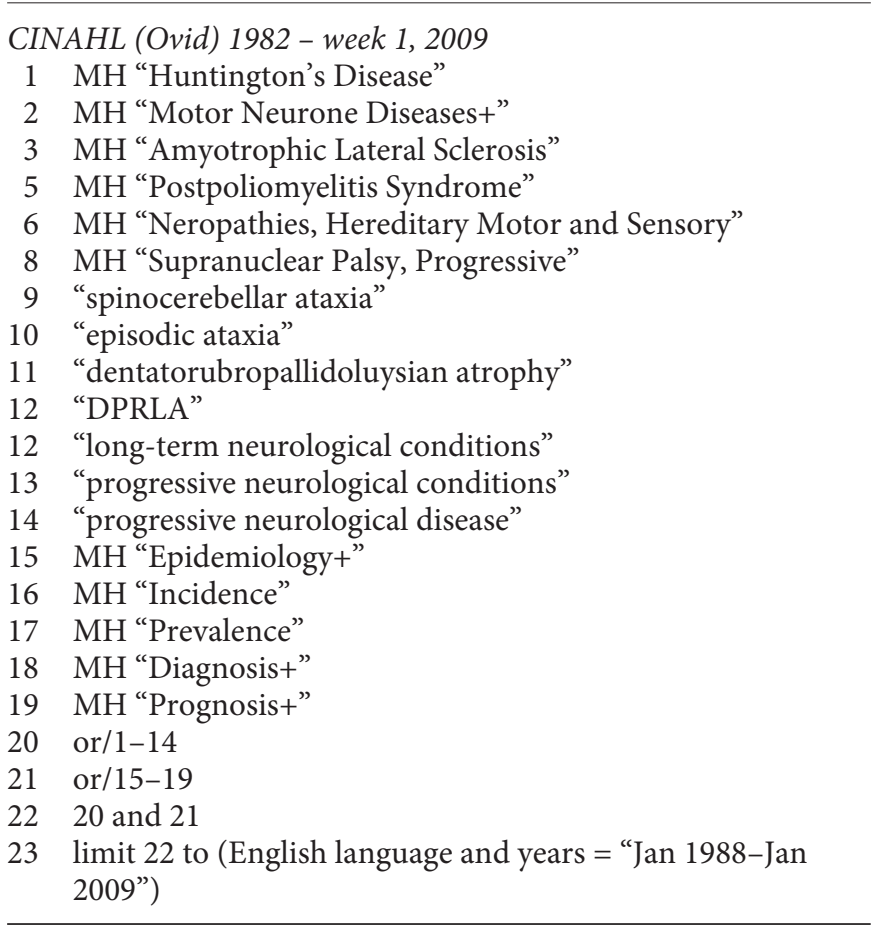

\section{Acknowledgements}

The authors would like to thank University of Birmingham librarian Nancy Graham for her expertise and assistance with developing the search strategy for the review. The review was conducted as part of a Policy Research Programme funded by the National Institute for Health Research.

\section{Appendix 2}
Diagnostic criteria
- Motor neurone disease: diagnosed by the El Escorial criteria [34] after 1994, and the WFN criteria before 1994 (definite, probable, possible and suspected categories)

- Huntington's disease: diagnosed by genetic test and/or presence of physical and psychological symptoms; confirmed by at least 1 neurologist

- Progressive supranuclear palsy: diagnosis confirmed by at least 1 neurologist

- Multiple system atrophy: diagnosis confirmed by at least 1 neurologist

- Postpolio syndrome: confirmation of polio virus in earlier life, and presence of symptoms

- Charcot-Marie-Tooth disease: diagnosis confirmed by family history and neurological tests

- Dominantly inherited ataxias: diagnosis by genetic and neurological tests

\section{Disclosure Statement}

The authors report no conflicts of interest.

\section{References}

1 Abhinav K, Stanton B, Johnston C, Hardstaff J, Orrell RW, Howard R, Clarke J, Sakel M, Ampong M-A, Shaw CE, Leigh PN, Al-Chalabi A: Amyotrophic lateral sclerosis in South-East England: a population-based study. The South-East England Register for Amyotrophic Lateral Sclerosis (SEALS Registry). Neuroepidemiology 2007;29:44-48.

$\checkmark 2$ Forbes RB, Colville S, Parratt J, Swingler RJ: The incidence of motor neuron disease in Scotland. J Neurol 2007;254:866-869.

-3 Johnson C, Stanton BR, Turner MR, Gray R, Blunt AH, Butt D, Ampong MA, Shaw CE, Leigh PN, Al-Chalabi A: Amyotrophic lateral sclerosis in an urban setting: a population-based study of inner city London. J Neurol 2006;253:1642-1643.

4 Mitchell JD, Gatrell AC, Al-Hamad A, Davies RB, Batterby G: Geographical epidemiology of residence of patients with motor neuron disease in Lancashire and south Cumbria. J Neurol Neurosurg Psychiatry $1998 ; 65: 842-847$.
5 James CM, Harper PS, Wiles CM: Motor neurone disease: a study of prevalence and disability. QJM 1994;87:693-699.

-6 Morrison PJ, Johnston WP, Nevin NC: The epidemiology of Huntington's disease in Northern Ireland. J Med Genet 1995;32:524530.

-7 James CM, Houlihan GD, Snell RG, Cheadle JP, Harper PS: Late-onset Huntington's disease: a clinical and molecular study. Age Ageing 1994;23:445-448

8 Watt DC, Seller A: A clinico-genetic study of psychiatric disorder in Huntington's chorea. Psychol Med 1993;(suppl 23):1-46.

$\checkmark 9$ Nath U, Ben-Shlomo Y, Thomson RG, Morris HR, Wood NW, Lees AJ, Burn DJ: The prevalence of progressive supranuclear palsy (Steele-Richardson-Olszewski syndrome) in the UK. Brain 2001;124(pt 7):1438-1449.
10 Craig K, Keers SM, Walls TJ, Curtis A, Chinnery PF: Minimum prevalence of spinocerebellar ataxia 17 in the north east of England. J Neurol Sci 2005;239:105-109.

11 Craig K, Keers SM, Archibald K, Curtis A, Chinnery PF: Molecular epidemiology of spinocerebellar ataxia type 6. Ann Neurol 2004;55:752-755.

12 Schrag A, Ben-Shlomo Y, Quinn NP: Prevalence of progressive supranuclear palsy and multiple system atrophy: a cross-sectional study. Lancet 1999;354:1771-1775.

$>13$ Simpson SA, Johnston AW: The prevalence and patterns of care of Huntington's chorea in Grampian. Br J Psychiatry 1989;155:799804.

14 Al-Chalabi A, Andersen PM, Nilsson P, Chioza B, Andersson JL, Russ C, Shaw CE, Powell JF, Leigh PN: Deletions of the heavy neurofilament subunit tail in amyotrophic lateral sclerosis. Hum Mol Genet 1999;8: 157-164. 
-15 Atsuta N, Watanabe H, Ito M, Tanaka F, Tamakoshi A, Nakano I, Aoki M, Tsuji S, Yuasa T, Takano H, Hayashi H, Kuzuhara S, Sobue G, Research Committee on the Neurodegenerative Diseases of Japan: Age at onset influences on wide-ranged clinical features of sporadic amyotrophic lateral sclerosis. J Neurol Sci 2009;276:163-169.

162001 census. Office for National Statistics.

172001 census for Scotland. General Register Office for Scotland.

- 18 Norris FH Jr, Calanchini PR, Fallat RJ, Panchari S, Jewett B: The administration of guanidine in amyotrophic lateral sclerosis. Neurology 1974;24:721-728.

19 Gubbay SS, Kahana E, Zilber N, Cooper G, Pintov S, Leibowitz Y: Amyotrophic lateral sclerosis: a study of its presentation and prognosis. J Neurol 1985;232:295-300.

-20 Ringel SP, Murphy JR, Alderson MK, Bryan W, England JD, Miller RG, Petajan JH, Smith SA, Roelofs RI, Ziter F, et al: The natural history of amyotrophic lateral sclerosis. Neurology 1993;43:1316-1322.

-21 Pradas J, Finison L, Andres PL, Thornell B, Hollander D, Munsat TL: The natural history of amyotrophic lateral sclerosis and the use of natural history controls in therapeutic trials. Neurology 1993;43:751-755.
22 Haverkamp LJ, Appel V, Appel SH: Natural history of amyotrophic lateral sclerosis in a database population: validation of a scoring system and a model for survival prediction. Brain 1995;118:707-719.

23 Mestre T, Ferreira J, Coelho MM, Rosa M, Sampaio C: Therapeutic interventions for symptomatic treatment in Huntington's disease. Cochrane Database Syst Rev 2009; 3:CD006456.

24 Golbe LI, Davis PH, Schoenberg BS, Duvoisin RC: Prevalence and natural history of progressive supranuclear palsy. Neurology 1988;38:1031-1034

25 Chio A, Magnani C, Schiffer D: Prevalence of Parkinson's disease in Northwestern Italy: comparison of tracer methodology and clinical ascertainment of cases. Mov Disord 1998;13:400-405.

26 Wermuth L, Joensen P, Bünger N, Jeune B: High prevalence of Parkinson's disease in the Faroe Islands. Neurology 1997;49:426-432.

27 Skre H: Genetic and clinical aspects of Charcot-Marie-Tooth's disease. Clin Genet 1974; 6:98-118.

28 Vasconcelos OM, Prokhorenko OA, Salajegheh MK, Kelley KF, Livornese K, Olsen $\mathrm{CH}$, Vo AH, Dalakas MC, Halstead LS, Jabbari B, Campbell WW: Modafinil for treatment of fatigue in post-polio syndrome: a randomized controlled trial. Neurology 2007;68:1680-1686.

-29 Chan KM, Amirjani N, Sumrain M, Clarke A, Strohschein FJ: Randomized controlled trial of strength training in post-polio patients. Muscle Nerve 2003;27:332-338.
30 On AY, Oncu J, Uludag B, Ertekin C: Effects of lamotrigine on the symptoms and life qualities of patients with post-polio syndrome: a randomized, controlled study. NeuroRehabilitation 2005;20:245-251.

-31 Gonzalez H, Sunnerhagen KS, Sjöberg I, Kaponides G, Olsson T, Borg K: Intravenous immunoglobulin for post-polio syndrome: a randomised controlled trial. Lancet Neurol 2006;5:493-500.

32 Farbu E, Rekand T, Vik-Mo E, Lygren H, Gilhus NE, Aarli JA: Post-polio syndrome patients treated with intravenous immunoglobulin: a double-blinded randomized controlled pilot study. Eur J Neurol 2007;14: 60-65.

33 Skough K, Krossén C, Heiwe S, Theorell H, Borg K: Effects of resistance training in combination with coenzyme $\mathrm{Q}_{10}$ supplementation in patients with post-polio: a pilot study. J Rehabil Med 2008;40:773-775.

34 Brooks BR: El Escorial World Federation of Neurology criteria for the diagnosis of amyotrophic lateral sclerosis. Subcommittee on Motor Neuron Diseases/Amyotrophic Lateral Sclerosis of the World Federation of Neurology Research Group on Neuromuscular Diseases and the El Escorial 'Clinical Limits of Amyotrophic Lateral Sclerosis' Workshop Contributors. J Neurol Sci 1994; 124(suppl):96-107. 